\title{
Salmonella Serotype Group B
}

National Cancer Institute

\section{Source}

National Cancer Institute. Salmonella Serotype Group B. NCI Thesaurus. Code C124380.

Characterization of salmonella bacteria subspecies as serotype group B based on the specific immunologic reactivity of cell surface lipopolysaccharide-protein chains called $O$ antigens. 